DOI: $10.15276 /$ ETR.03.2020.4

DOI: $10.5281 /$ zenodo.5201632

UDC: 658.012

JEL: E 30, O33

\title{
BASICS OF ENTERPRISE STRATEGY DEVELOPMENT ON THE EXAMPLE PJSC "HEMOPLAST"
}

\section{ОСНОВИ РОЗРОБКИ СТРАТЕГІЇ РОЗВИТКУ ПІДПРИЕМСТВА НА ПРИКЛАДІ ПАТ «ГЕМОПЛАСТ»}

Oksana I. Prodius, $\mathrm{PhD}$ in Economics, Associate Professor

Odessa National Polytechnic University, Odessa, Ukraine ORCID: 0000-0002-0619-7567

Email: o.i.prodius@gmail.com

Anna R. Arkushenko Odessa National Polytechnic University, Odessa, Ukraine ORCID: 0000-0001-8376-6009

Email: arkushenko98@gmail.com

Oleg O. Krivorotenko Odessa National Polytechnic University, Odessa, Ukraine ORCID: 0000-0002-4686-3739

Email: krivorotenko.83oleg@gmail.com

Received 26.05.2020

Продіус О.І., Аркушенко А.Р., Криворотенко О.О. Основи розробки стратегії розвитку підприємства на прикладі ПАТ "Гемопласт». Оглядова стаття.

У статті досліджено та систематизовано поняття стратегії розвитку підприємства. Розглянуто концептуальні основи формування стратегії розвитку підприємства. Відокремлено та проаналізовано головні етапи розробки стратегії згідно 3 особливостями корпоративного, бізнес- та функціонального рівнів управління. Визначено загальні характеристики розробки та класифікація стратегій розвитку підприємства в сучасних умовах господарювання. Розглянуто основні елементи та складові економічного розвитку підприємства у контексті стратегічного менеджменту.

Ключові слова: стратегія розвитку підприємства, розробка стратегії, етапи стратегії, класифікація стратегій, SWOT-аналіз, характеристика стратегій розвитку

Prodius O.I., Arkushenko A.R., Krivorotenko O.O. Basics of enterprise strategy development on the example PJSC "Hemoplast". Review article.

The article investigates and systematizes the concepts of an enterprise development strategy. The conceptual foundations of the enterprise development strategy formation are considered. The main stages of strategy development in accordance with the characteristics of the corporate, business and functional levels of management are separated and analyzed. The general characteristics of the eleboration and classification of the enterprise development strategies in modern economic conditions are determined. The main elements and components of the enterprise economic development in the context of strategic management are considered.

Keywords: an enterprise development strategy, strategy development, strategy stages, strategy classification, SWOTanalysis, development strategies characteristics
$\mathrm{T}$

he market environment in which enterprises operate at this stage of economic development in the world is a high risk due to the international political and economic aspectsinstability, such as the epidemic situation, market oversaturation, increasing the of innovative goods share etc. Enterprises face the problem of development in connection with economic crises, namely with raising uncertainty of managerial decisions, increasing the risk of the enterprise in achieving the planned results.

Among the scientific approaches in order to improve the enterprise efficiency one can involve elaborating the development strategy that helps to plan, monitor and find solutions for the enterprise critical areas. The enterprise development strategy is an integral part of its work, which determines a modern manager's priority - the development strategy definition taking into account the main mission and individual characteristics of the enterprise. At different levels, employees need to know the main strategy goals and ways to achieve them.

Carefully thought-out strategy allows the company management to solve not just the current tasks of business development every day, but the current tasks that work for the main goal and the main prospect. On the strategy basis the target planning which allows to reduce expenses of material, labour and financial resources at achieving the enterprise strategic purposes is carried out. In these circumstances, it is important to develop a strategy that will allow the company to avoid unplanned costs associated with its strategic activities. 


\section{Analysis of recent researches and publications}

Issues related to the elaboration of the enterprise development strategy were considered by the prominent scientists in the field of strategic management, such as: I. Ansoff, P. Drucker and M. Porter.

Methodological implementation bases of the enterprise development strategy were considered in research papers of domestic scientists: H.M. Azarenkova, M.M. Aleksieieva, L.V. Balabanova, M.I. Bakanov, O.A. Bohomolova, V.H. Herasymchuk, O.H. Holovko, S.M. Zhukevych, M.I. Kovalchuk, I.D. Lazaryshynoi, Ye.V. Mnykh, S.Z. Moshenskyi, V.S. Ponomarenko, A.I. Pushkar, O.H. Cherep and others. Despite the sufficient number of scientific papers on this issue, some aspects are not sufficiently considered, namely the development strategy features in accordance with the industry and the specific features of the enterprise.

The purpose of the article is to study the theoretical and methodological approaches to the implementation of the enterprise development strategy, as well as the enterprise development strategy formation on the example of "Hemoplast" PJSC based on its strategic analysis.

\section{The main part}

In general, the concept of «enterprise development strategy» involves planning and providing effective ways of decision-making, which are a holistic reflection of the enterprise economic development goals and means.

Based on the table 1 definitions of famous scientists, let's add the concept of "enterprise strategy" as follows: enterprise strategy - is a system of managerial influences on economic and organizational relations of the enterprise labour collectives, aimed at achieving the enterprise goals and ensuring effective operation and the enterprise development in the short and long term.

The notion of strategy is defined as a comprehensive programme of actions, which is based on its mission, main objectives and identifies the problems that are prioritized for the company, and the resources allocation to achieve them.

The strategy, as a result of strategic planning in the enterprise is a long-term integral document.

Strategic planning is a process of carrying out a set of systematic and mutually agreed actions with the definition of long-term (strategic) goals and the enterprise activities.

The main characteristics of the enterprise development strategy are shown in the Figure 1.

The process of company strategy development includes the following levels:

- Corporate level. It is developed in theoretical form. The head of the enterprise is responsible for its implementation. This level is in the nature of long-term development and is aimed at making long-term goals.

- Business level. Specific boundaries of activity are defined by setting goals and objectives. It is determined what the company needs to achieve specifically (goals), what needs to be achieved (tasks).

- Functional level is defined as the direction of a functional service activity within the same business sphere. This level is aimed at realising the goals and targets set at the business level. Its processes include detailing strategic objectives related to the business level as well as analysing the enterprise external and internal environment.

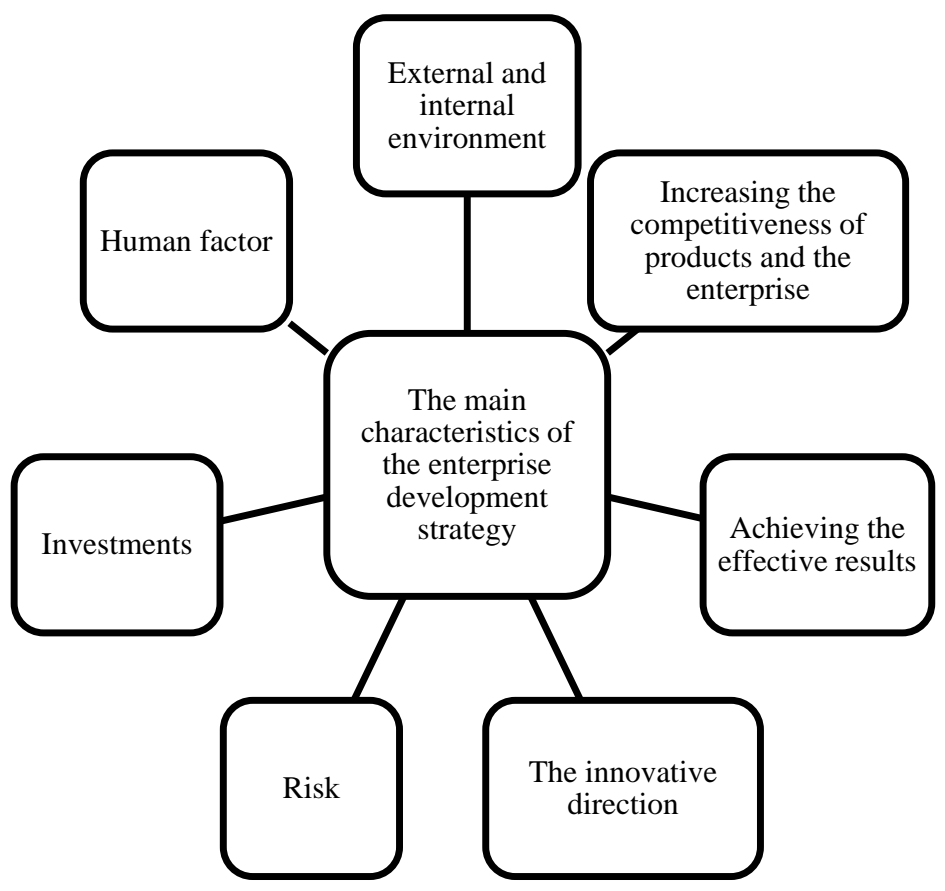

Figure 1. The Main Characteristics that Reflect the Essence of the Enterprise Development Strategy Source: compiled by autor on materials [1]. 
Table 1. The List of Approaches to the Essence of "the Enterprise Development Strategy"

\begin{tabular}{|c|c|c|}
\hline № & The Essense & Author \\
\hline 1 & $\begin{array}{l}\text { The concept of the enterprise strategy combines two stages: the strategy } \\
\text { implementation and the apparatus development. The essence is to describe the } \\
\text { future behaviour of the enterprise against the dynamics background of the the } \\
\text { development strategy plan implementation. The strategy should ensure the } \\
\text { process effectiveness, taking into account limited resources and changing } \\
\text { environmental factors. }\end{array}$ & S.M.Vasylyha \\
\hline 2 & $\begin{array}{l}\text { This concept integration is a combination of strategic directions and functional } \\
\text { planning strategies. Ensuring the competitiveness and positive movement of } \\
\text { the enterprise is based on a set of norms, guidelines and rules that reflect the } \\
\text { enterprise strategy. }\end{array}$ & I. Denysiuk \\
\hline 3 & $\begin{array}{l}\text { The strategy formation for the enterprise should include the dynamics of its } \\
\text { development in a turbulent environment and the realization of the purpose of } \\
\text { the enterprise on the basis of rational use of resources. }\end{array}$ & M.H .Saienko \\
\hline 4 & $\begin{array}{l}\text { The main idea of the strategy formation is a clear definition of the company } \\
\text { goals, understanding of what resources and actions can reach point B, and } \\
\text { what methods the company uses to achieve the goal. }\end{array}$ & M. Porter \\
\hline 5 & $\begin{array}{l}\text { The strategy development is implemented on the basis of a generalized model } \\
\text { of action for the resources coordination and allocation aimed at achieving the } \\
\text { enterprise long-term goals. }\end{array}$ & A.T. Zub \\
\hline 6 & $\begin{array}{l}\text { Achieving the enterprise desired results and goals is based on a clearly defined } \\
\text { management plan of the company and is presented in the form of strategic } \\
\text { directions, tasks and control points of the strategy effectiveness. }\end{array}$ & V. Makedon \\
\hline 7 & $\begin{array}{l}\text { The system plan development for the enterprise behaviour in the conditions of } \\
\text { aggressive and unpredictable environment and incomplete information on its } \\
\text { development. }\end{array}$ & I. B. Dehtiarova \\
\hline 8 & $\begin{array}{l}\text { The complex of the enterprise functioning in relation to the mission and form } \\
\text { of its activities, position in the external environment, communication systems } \\
\text { in the enterprise and its resource capabilities. }\end{array}$ & O.S. Vikhanskyi \\
\hline 9 & $\begin{array}{l}\text { Based on the indicators system of quantitative and qualitative analysis, which } \\
\text { clearly reflect the enterprise development parameters and demonstrate the } \\
\text { stage of achieving the goals at which the business entity is located. }\end{array}$ & M. V. Khatser \\
\hline
\end{tabular}

Source: compiled by autor on materials [1,4,5].

Let's define the following basic elements of the enterprise economic development strategy:

- the organization mission;

- the organization strategic goals;

- the period of the strategy validition;

- ways to formalize the strategy (strategy is presented in the form of a system of tactical plans, programmes, budgets);

- organizational structure of the enterprise management and personnel;

- organizational culture;

- resource management methods (methods of accounting, analysis, planning, forecasting, control, regulation, budgeting, business reengineering);
— information support of the management process and management technical means;

- the set of the enterpriseresources and their characteristics;

- the enterprise financing sources ;

- a set of the enterprise external and internal relations (interaction with other organizations, financial and credit system, relations within the enterprise, enterprises associations);

- risk factors of financial and economic activities;

— indicators and methods for assessing the development strategies effectiveness;

- strategic management area;

- strategic economic centre.

Let's consider the basic classification of the enterprise development strategies in the table. 2.

Table 2. The Enterprise Development Strategies Classification

\begin{tabular}{|l|l|}
\hline The Classification Pattern & The Type of Strategy Development \\
\hline \multicolumn{1}{|c|}{ The type of economic growth } & $\begin{array}{l}\text { The concentrated growth strategy. } \\
\text { The diversified growth strategy. } \\
\text { The integrated growth strategy. }\end{array}$ \\
\hline & $\begin{array}{l}\text { The strategy that supports zero growth rates. } \\
\text { Limited growth strategy. } \\
\text { The enterprise development rates } \\
\text { Acceled growth strategy. } \\
\text { Anticipatory growth strategy. }\end{array}$ \\
\hline direction & $\begin{array}{l}\text { The organic growth strategy. } \\
\text { The integration strategy. }\end{array}$ \\
\hline
\end{tabular}


Continuation of Table 2

\begin{tabular}{|l|l|}
\hline \multicolumn{1}{|c|}{1} & \\
\hline Attitude to the enterprise & $\begin{array}{l}\text { The external growth strategy. } \\
\text { The internal growth strategy. }\end{array}$ \\
\hline The activities diversification & $\begin{array}{l}\text { The concentric diversification strategy (mono-industry). } \\
\text { The strategy of conglomerate diversification (multisectoral) }\end{array}$ \\
\hline $\begin{array}{l}\text { Funding sources and their } \\
\text { involvement conditions }\end{array}$ & $\begin{array}{l}\text { The strategies that use mostly their own of funding sources. } \\
\text { The strategies that use mostly borrowed funding sources. } \\
\text { The Strategies that use mixed funding sources. }\end{array}$ \\
\hline $\begin{array}{l}\text { The level of making strategic } \\
\text { decisions }\end{array}$ & $\begin{array}{l}\text { The corporate strategy } \\
\text { The business units strategies (strategic business centers). }\end{array}$ \\
\hline The operational activities scale & $\begin{array}{l}\text { The strategy for expanding theoperational activities scale. } \\
\text { The strategy for maintaining the operational activitiesscale } .\end{array}$ \\
\hline The market expansion scale & $\begin{array}{l}\text { The market segment conservation strategy. } \\
\text { The strategy for transition to another market segment. }\end{array}$ \\
\hline \multicolumn{2}{|c|}{ Source: }
\end{tabular}

Source: compiled by autor on materials [7].

The enterprise development strategy elaboration as a system should be carried out in stages. Also a necessary measure in strategy planning is to take into account the destabilizing influence of the state on the enterprise activities.
Let's highlight the following stages of enterprise development strategy elaboration at Ukrainian enterprises in the table 3 .

Table 3. The Strategy Elaboration Stages at the Enterprise

\begin{tabular}{|l|l|}
\hline Stages & The Stage Content \\
\hline 1 & Studying or determining the enterprise mission. \\
\hline 2 & $\begin{array}{l}\text { Studying the external environment for the enterprise and determine its direct impact on the enterprise. At } \\
\text { this stage, special attention should be paid to the instability factors in the economy of Ukraine (crises, } \\
\text { remnants of command - administrative system of economic management, corruption, the presence of a } \\
\text { significant number of economic reforms, the state levers inefficiency influencing the economy, etc.). }\end{array}$ \\
\hline 3 & $\begin{array}{l}\text { Conducting analysis the enterprise strengths and weaknesses, as well as its capabilities and threats. It is } \\
\text { recommended to use SWOT analysis. }\end{array}$ \\
\hline 4 & $\begin{array}{l}\text { Defining and forming the enterprise goals on the basis of analysis in the future for 5-10 years depending } \\
\text { on the enterprise status. }\end{array}$ \\
\hline 5 & $\begin{array}{l}\text { Exploring alternatives for enterprise strategy development and their assessment and risks identification. } \\
\text { The measures implementation that were defined as strategic actions to increase the level of the enterprise } \\
\text { economic activities. }\end{array}$ \\
\hline 7 & $\begin{array}{l}\text { Evaluation and monitoring the process of the enterprise development strategy implementation, and } \\
\text { necessary adjustment introduction s. }\end{array}$ \\
\hline 8 & $\begin{array}{l}\text { Evaluation of development strategy and its effectiveness analysis, use existing data in the development of } \\
\text { new strategies. }\end{array}$ \\
\hline
\end{tabular}

Source: compiled by autor on materials [2,6].

Thus, on the basis of the abovementioned theoretical aspects, let's consider the public joint stock company "Hemoplast", which is the full successor of the Open Joint Stock Company, established on the basis of the decision of State Committee of Ukraine for Medical and Microbiological Industry dated 28 February 1994 № 17 and manufactures medical devices on the basis of polymeric materials. According to the Decree of the President of Ukraine "On Corporatization of Enterprises", the state enterprise BelgorodDniestovsky Plant of Medical Devices from Polymeric Materials was transformed into an open joint-stock company on 15 June 1993. After changing the form of the joint-stock company in 2011, the company was renamed into "Hemoplast" PJSC .

The medical devices composition produced by

"Hemoplast" PJSC includes:

- blood transfusion devices;

- devices for the injection of blood substitutes and infusion solutions;
- devices for taking blood from a donor;

- disposable injection syringes with a capacity of $0.5 ; 1 ; 2 ; 5 ; 10 ; 20 ; 50 \mathrm{ml}$;

- 13 names of catheters and probes for medical purposes;

- a wide range of products for patient care;

- more than 100 items of goods for the house from polymers (mainly from waste of the main production).

The manufactured products relevance is high, because among the medical devices there are not any substitutes for blood transfusion devices, syringes and other devices for medical use. The enterprise adheres to high standards of industrial hygiene, so all devices are sterile and are individually packaged. Also, all materials are biologically compatible with the human body.

As for the sales system, the enterprise products depend on the population's welfare. After all, according to statistics from countries with higher average earnings, the number of similar products 
consumption is almost twice as high. Also, the company products do not fluctuate greatly depending on the season, there are a number of goods that are consumed equally year all the year round (syringes and blood transfusion devices). In the field of disposable medical devices production «Hemoplast» PJSC is a clear leader in Ukraine and is also gradually conquering the market of Eastern Europe. Production capacity is high, and therefore the company potential is sufficient to expand the market.

Regarding the competition in the domestic market, due to the high saturation of its disposable medical devices by various companies, both Ukrainian and international, the competition is quite fierce. Among the criteria that consumers pay attention to is the product price and its quality, today «Hemoplast» PJSC cannot compete with other companies in the price criterion, because due to the high cost of production, the product price is above average. But the manufactured products quality is higher than in most Eastern European and CIS competitors. The Figure 2 shows a list of competitors that most influence the products sale of "Hemoplast" PJSC.

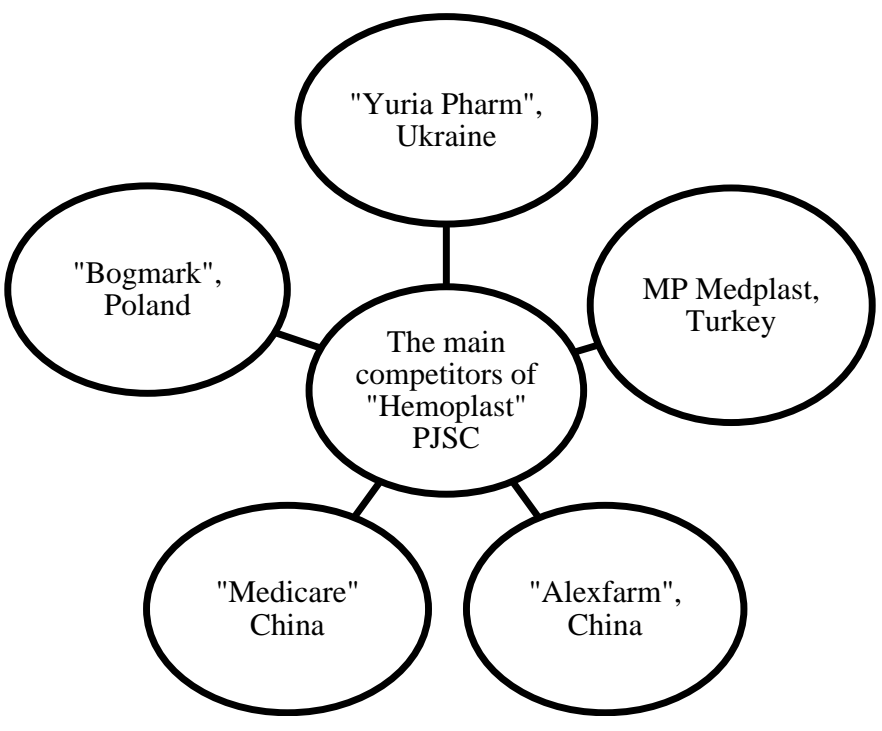

Figure 2. The Main Competitors of PJSC "Hemoplast" Source: compiled by autor on materials [3].

The European market is characterized by high competition, especially on the part of Russian manufacturers, because the products price is low, because the cost of resources for production (polymer raw materials and energy) in Russia is lower, but these products quality is difficult to call high.
"Hemoplast" PJSC holds a leading position due to the quality of finished products, because in terms of prices for products of competitors from Russia and China are cheaper.

Let's consider the SWOT-analysis of "Hemoplast" PJSC in the table 4.

Table 4. The SWOT-Analysis of "Hemoplast" PJSC

\begin{tabular}{|c|c|}
\hline Strong points (S) & Weak points(W) \\
\hline $\begin{array}{l}\text { 1. Favourable geographical location of the } \\
\text { enterprise in relation to suppliers and consumers. } \\
\text { 2. High professionalism of engineering and } \\
\text { technical staff. } \\
\text { 3. High quality of manufactured products, which } \\
\text { is competitive on the CIS and Eastern European } \\
\text { market. }\end{array}$ & $\begin{array}{l}\text { 1. Lack of marketing strategy. } \\
\text { 2. Lack of a clear strategy for enterprise development. } \\
\text { 3. Imperfect risk reduction system. } \\
\text { 4. High level of competitiveness due to low production costs. } \\
\text { 5. Obsolete basis of production assets. } \\
\text { 6. Chemical production that harms the environmental situation. }\end{array}$ \\
\hline Opportunities $(\mathbf{O})$ & Threats(T) \\
\hline $\begin{array}{l}\text { 1. Expanding the product range. } \\
\text { 2. Studying the innovative medical devices that } \\
\text { are not available on the Ukraine's market or } \\
\text { their number is insufficient. } \\
\text { 3. Conducting advertising campaigns to spread } \\
\text { consumer awareness of products. } \\
\text { 4. Using the enterprise resources is efficient for } \\
\text { making a profit. }\end{array}$ & $\begin{array}{l}\text { 1. High cost of manufactured products. } \\
\text { 2. Limited opportunities for sales in the domestic market due to the } \\
\text { imports expansion. } \\
\text { 3. Reducing the share of skilled labour resources with higher } \\
\text { education in the labor market. }\end{array}$ \\
\hline
\end{tabular}

Source: authors' own development 
Based on the SWOT-analysis (Table 4), we offer the following strategies for the enterprise development:

WT- strategy:

1. Creating the marketing strategy to increase the enterprise share in the domestic market.

2. Increasing staff motivation and attracting young professionals after graduation to work at the enterprise.

3. Using the high-tech equipment in order to reduce production costs. ST-strategy:

1. Participation in international advertising fairs, in order to increase the exports share.

2. Establishing partnerships with foreign suppliers.

3. Rapid response of the enterprise to changes in the consumers' needs in the pandemic conditions. WO-strategy:

1. Updating the production assets.

2. Maintaining the company image by manufacturing products that meet consumer needs

3. Obtaining competitive advantages by optimizing the products structure.

4. Introducing the environmentally friendly production. SO-strategy:

1. Establishing the representative offices of the company in European countries.

2. Introducting new resource-saving production technologies.
Thus, the main stage of developing the enterprise strategy includes its activities analysis by SWOTanalysis, which helps to justify the enterprise main characteristics, in accordance with the peculiarities of its internal and external environment.

\section{Conclusions}

On the example of the enterprise "Hemoplast" PJSC was demonstrated the process of elaborating the development strategy taking into account all levels of management, such as: corporate level, developed in theoretical form; business level, specific boundaries of activity are determined by setting goals and objectives, the functional level is defined as the direction of the functional service within one area of the enterprise business.

As a result of the study, it was determined that the process of eleborating the enterprise development strategy includes a number of stages in finding problems, identifying solutions, monitoring and control of work performed. The enterprise development strategy formation as a system should be carried out in stages and respond quickly to changes in the external and internal environment.

The conducted study has proved that there is no single reference strategy for companies in all industries. Each business entity and its activities are unique, which determines the development strategy originality.

\begin{abstract}
Purpose of the article. The market environment in which enterprises operate at this stage of economic development in the world is a high risk due to the instability of international political and economic aspects, such as the epidemic situation, market oversaturation, increasing the share of innovative goods and others. Enterprises face the problem of development in connection with economic crises, namely with increasing uncertainty of management decisions, increasing the risk of the enterprise in achieving the planned results. Among the scientific approaches to improve the efficiency of the enterprise can be developed a development strategy that helps to plan, monitor and find solutions for critical areas of the enterprise. The strategy of enterprise development is an integral part of its work, which determines the priority of the modern manager - determining the development strategy taking into account the main mission and individual characteristics of the enterprise.

Research Methodology. The main methodological method of research is the system-structural approach, which allows the most effective organization of the search for the solution of the tasks. Also, methods of comparative, functional analysis, classification are used. Theoretical and methodological basis of work were theoretical positions and scientific principles, developed by domestic and foreign specialists in the field of definition of development strategy at the enterprise.

Results. At different levels, employees need to know the main goals of the strategy and ways to achieve them. Carefully thought-out strategy allows the company's management to solve every day not just current business development tasks, but current tasks that work for the main goal and the main prospect. Based on the strategy, targeted planning is carried out, which reduces the cost of material, labor and financial resources in achieving the strategic goals of the enterprise. In these circumstances, it is important to develop a strategy that will allow the company to avoid unplanned costs associated with its strategic activities. The concept of strategy is defined as a comprehensive program of action, which is based on its mission, main objectives and identifies the problems that are a priority for the company, and the allocation of resources to achieve them. The strategy, as a result of strategic planning in the enterprise is a long-term integral document. Strategic planning is a process of carrying out a set of systematic and mutually agreed work with the definition of long-term (strategic) goals and activities of the enterprise.

Novelty. On the example of the enterprise PJSC "Hemoplast" was demonstrated the process of developing a development strategy taking into account all levels of management, such as: corporate level, developed in theoretical form; business level, specific boundaries of activity are determined by setting goals and objectives, the functional level is defined as the direction of the functional service within one area of business of the enterprise.
\end{abstract}


The practical significance. As a result of the study, it was determined that the process of developing an enterprise development strategy includes a number of stages in finding problems, identifying solutions, monitoring and control of work performed. The formation of a strategy for the development of the enterprise as a system should be carried out in stages and respond quickly to changes in the external and internal environment.

\section{Список літератури:}

1. Гудзь О.І. Стратегія розвитку підприємства: сутність та класифікація / О. І. Гудзь. // Мукачівський Державний Університет. - 2018. - С. 346-352.

2. Минцберг Г. Стратегічний процес: концепції, проблеми, рішення. / Г. Минцберг, Дж. Куинн, Б. Гулаш. - СПб.: «Питер», 2001. - 684c.

3. Річна інформація емітента цінних паперів (річний звіт) за 2019 рік [Електронний ресурс] // ПАТ «Гемопласт». - $\quad 2019 . \quad$ - $\quad$ Режим доступу до ресурсу: https://hemoplast.ua/storage/files/ZVIT_Gemoplast_2019.pdf.

4. Саєнко М.Г. Стратегія підприємства / М. Г. Саєнко. - Тернопіль, 2006. - 390 с.

5. Дегтярьова І.Б. Стратегія підприємства / І. Б. Дегтярьова, М. О. Харченко. - Суми, 2016. - 80 с.

6. Пуцентейло П.Р. Стратегічний аналіз як важливий елемент управління підприємством / П. Р. Пуцентейло, О.О. Гуменюк. // статистика, облік, аналіз та аудит. - 2018. - С. 197-205.

7. Бродюк I.В. Стратегічний аналіз інвестиційного розвитку підприємства / І.В.Бродюк. // Економічна наука. - 2019. - С. 131-133.

\section{References:}

1. Gudz O.I. (2018). Strategy of an Enterprise Development: Essence and Classification. Mukachevo State University [in Ukrainian].

2. Minzberg G., Quinn J., Goulash B. (2001). Strategic Process: Concepts, Problems, Solutions [in Ukrainian].

3. Annual Information of the Issuer of Securities (Annual Report) for 2019 - Retrieved from: https://hemoplast.ua/storage/files/ZVIT_Gemoplast_2019.pdf [in Ukrainian].

4. Saenko M.G. (2006). Strategy of the Enterprise. Ternopil [in Ukrainian].

5. Dehtiarova I.B., Kharchenko M.O. (2016). Strategy of the Enterprise. Sumy [in Ukrainian].

6. Putsenteilo P.R., Humeniuk O.O. (2018). Strategic Analysis as an Important Element of an Enterprise Management. Statistics, Accounting, Analysis and Audit [in Ukrainian].

7. Brodyuk I.V. (2019). Strategic Analysis of Investment Development of Enterprise. Economic science [in Ukrainian].

\section{Посилання на статтю:}

Prodius O.I. Basics of enterprise strategy development on the example PJSC "Hemoplast"/ O. I. Prodius, A. R. Arkushenko, O. O Krivorotenko // Економіка: реалї̈ часу. Науковий журнал. - 2020. - № 3 (49). - C. 35-41. Режим доступу до журн.: https://economics.opu.ua/files/archive/2020/No3/35.pdf. DOI: 10.15276/ETR.03.2020.4. DOI: 10.5281/zenodo.5201632.

\section{Reference a Journal Article:}

Prodius O.I. Basics of enterprise strategy development on the example PJSC "Hemoplast"/ O. I. Prodius, A. R. Arkushenko, O. O Krivorotenko // Economics: time realities. Scientific journal.- 2020. - № 3 (49).- P. 35-41. Retrieved from https://economics.opu.ua/files/archive/2020/No3/35.pdf. DOI: 10.15276/ETR.03.2020.4. DOI: 10.5281/zenodo.5201632. 